\title{
PHYSIOGRAPHIC PROVINCES AND SECTIONS IN WESTERN OKLAHOMA AND ADJACENT PARTS OF TEXAS.
}

\author{
By Nevin M. Fenneman.
}

\section{GENERAL FEATURES OF THE AREA.}

Physiographic provinces.-The area here considered is a part of the interior plains of the United States, which is an extensive region of relatively slight relief and nearly horizontal beds of rock that is divided between the Great Plains province, its western part, and the Central Lowland, its eastern part. The boundary between these two physiographic provinces runs in general southward and lies not far from the one hundredth meridian - the meridian that forms the eastern boundary of the Texas "panhandle."

The most obvious difference between the Great Plains and the Central Lowland is one of altitude, for the plains are generally about 2,000 feet above sea level near their eastern edge and increase in height toward the west, whereas the lowland is everywhere below 2,000 feet. The boundary line between the provinces throughout most of its extent is drawn at the foot of an escarpment, or at least at the foot of an eastward slope, which is steeper than the average slope from the Rocky Mountains to Mississippi River. At some places it is clear that the lowland is expanding westward by continued erosion and that the escarpment which separates the plains and the lowland is retreating westward, and it is therefore evident that the lower surface of that part of the Central Lowland has been produced by the wearing down of the Great Plains, which formerly extended farther east.

Both the Great Plains and the Central Lowland may be divided into sections that differ somewhat in topography. Those represented in this area are the High Plains section of the Great Plains and the Osage section of the Central Lowland.

High Plains section of the Great Plains.-The High Plains are remnants of a once continuous plain whose surface was formed of Tertiary silt, sand, and gravel. This plain stretched from the Rocky 
Mountains eastward beyond the present limits of the Great Plains, at a slope of not more than 10 feet to the mile. This once broad belt has been narrowed by erosion on both sides and is crossed from west to east by a few rivers, which have cut deep valleys, but the remnants of the original plain still dominate the landscape in the belt that is called the High Plains section.

These plains are typically exemplified in the Texas "panhandle," which lies along the western margin of the area herein described. Their treeless surface is essentially flat except for some valleys eroded near their eastern edge and near the large streams. They include also some wide, shallow depressions, some of which contain lakes, but none of these features are sufficiently pronounced to offset the general impression of flatness.

Generally along the eastern edge of the High Plains section there is a steep slope down to the Central Lowland. Throughout much of its extent this steep slope is an actual escarpment-the "break of the plains" -300 to 600 feet high, at some places straight, at others made irregular by the erosion of streams that head in the plateau and flow eastward.

Osage section of the Central Lowland.-The southwestern part of the Central Lowland, known as the Osage section, shows throughout its extent the character of a surface produced by degradation. The formations dip slightly toward the west or northwest and have been planed off, so that their edges crop out in belts that trend nearly southward. The outcropping edges of the more resistant members give rise to eastward-facing escarpments, which are generally 50 to 200 feet high. All these escarpments have been more or less dissected, some of them so much that hilly belts several miles wide have taken the place of what may once have been simple escarpments. On the intervening less resistant formations, most of them composed of shale, are broad, smooth surfaces. The alternation of these two types of topography is sufficiently common to suggest the term "scarped plains," which is often applied to the Osage section.

Several of the escarpments are exceptionally high and rugged. One, between Cimarron and Canadian rivers, in western Oklahoma, which marks the outcrop belt of the Blaine formation (fig. 43), extends from the Kansas boundary southeastward halfway across the State and is the most prominent of the several hilly tracts bearing the name Gypsum Hills. The other high escarpments lie mainly in Texas and die out toward the north in the vicinity of Red River. The highest and most rugged of these escarpments, which is made by beds of resistant limestone, lies a little west of the ninety-ninth meridian. Although these escarpments contrast strongly in topography with the smooth plains on either side, they belong to the same 
general class with others in the Osage section of the Central.Lowland, as the surface west of them is not very different in general character from that on the east.

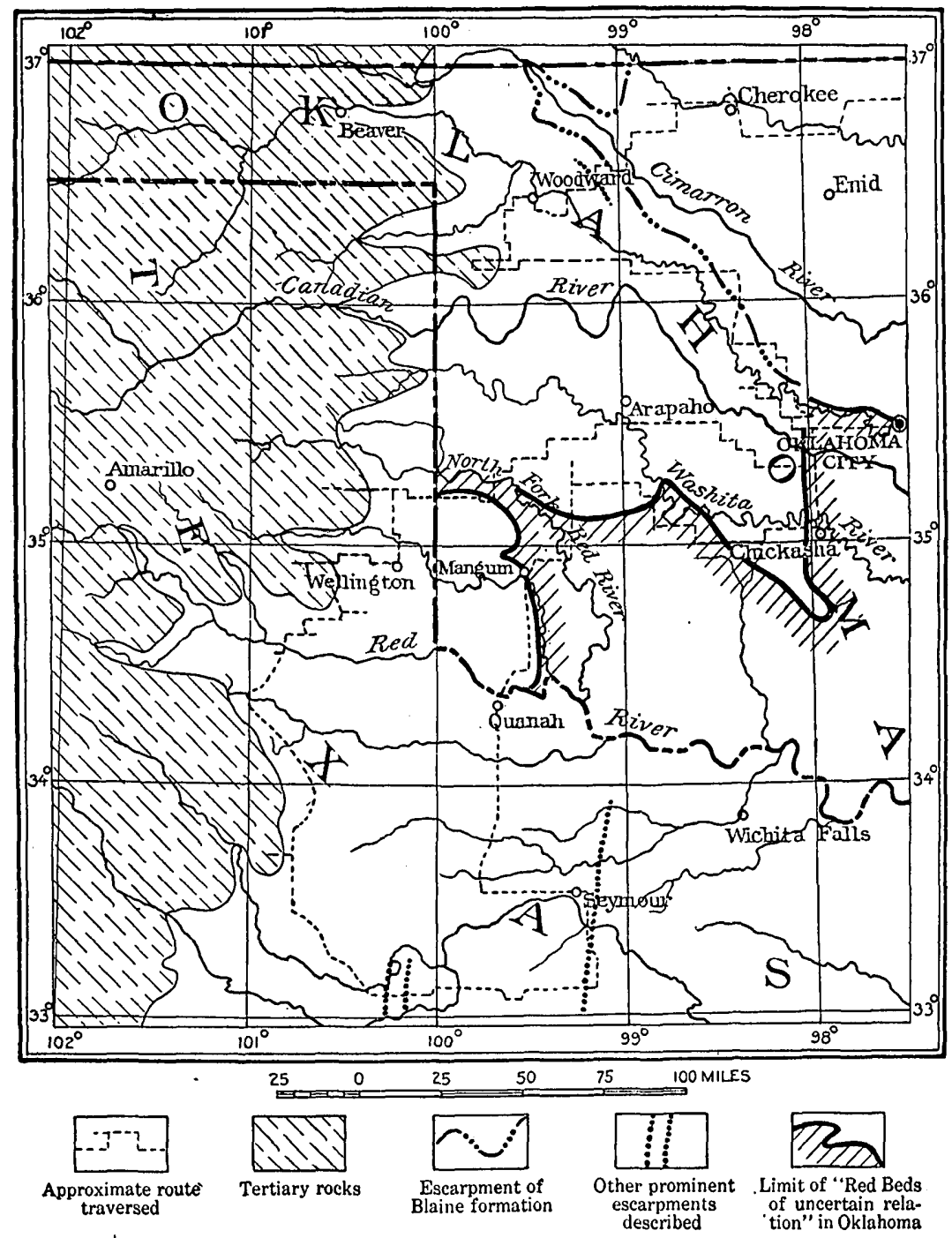

Figdre 43.-Index map of western Oklahoma and adjacent parts of Texas.

\section{NATURE OF THE INVESTIGATION.}

Problem of the "Plains Border."-The study described in this paper concerns the character of the country just east of the High Plains. It has been assumed by geographers that a strip 25 to 75 miles wide, characterized by a rougher surface, intervenes between the High Plains and the typically developed Central Lowland. This 
strip has been called the "Plains Border" and classed as a section of the Great Plains province. It has been defined as follows :

Consider these plains [the High Plains in their original extent] to have been a uniform smooth surface stretching from the mountains to eastern Nebraska and Kansas. The central strip or High Plains [section] is what is left of this flat surface, still covered by the late Tertiary beds to which the tlatness is due. The Plains Border is the strip on the east from which the Tertiary mantle has been in large part eroded and which is now dissected but not reduced to the low relief which characterizes the Central Lowland. It is in general a hilly country. ${ }^{1}$

This description was written with immediate reference to the part of the province lying in the latitude of Kansas. From the scanty physiographic information available for western Oklahoma and adjacent parts of Texas it was inferred that a similar division of the Great Plains province was applicable also to that region.

In the paper cited above it was assumed that the eastern front of the Gypsum Hills from the Kansas boundary to central Texas constitutes a fairly definite boundary between the typical lowlands of the Osage section on the east and a rougher region, less perfectly base-leveled, on the west. It was to test this assumption that the field investigation here recorded was undertaken. The question to be answered was: Should a distinct physiographic section be recognized between the High Plains and the Central Lowland in western Oklahoma and northern Texas?

Manifestly the boundary between a high plain and a continuous low plain can nowhere be merely a line, even if so represented on a map, and it must therefore be assumed that the two are separated by at least a narrow transitional belt, roughened by dissection but not base-leveled, even if such a belt has not been specifically mentioned. The propriety of treating this rougher strip as a distinct physiographic section depends partly on its width.

Conclusions.-It may be stated in advance that the result of the field investigation has led to the conclusions that the lower area next east of the High Plains has a generally uniform character from east to west and that it should not be divided and its parts allotted to different provinces. It is also doubtful whether any contrast between its eastern and western parts is sufficient to justify the setting up of two sections. Future detailed studies will probably enable the physiographer to recognize several divisions of a lower order, and in delimiting these divisions the minor scarps should doubtless be considered. The provinces and sections, as revised through this investigation, are shown in figure 44, in which the name "Smoky Hills section" is applied to what remains of the "Plains Border."

${ }^{2}$ Assoc. Am. Geographers Annals, vol. 6, p. 70, 1917. 
Field work.-The field work underlying this study was a reconnaissance by automobile made in five weeks beginning June 15, 1921. The writer, assisted by Waldo S. Glock, followed a zigzag course (fig. 43) across the belt from northern Oklahoma to the parallel of $33^{\circ}$ in Texas, about 100 miles south of Red River. The total distance traveled was approximately 1,450 miles, two-thirds of it in Oklahoma. The course followed led from Pawhuska, in Osage County, westward to the Gypsum Hills west of Alva; thence south and west to Arnett, on the High Plains in Ellis County; thence

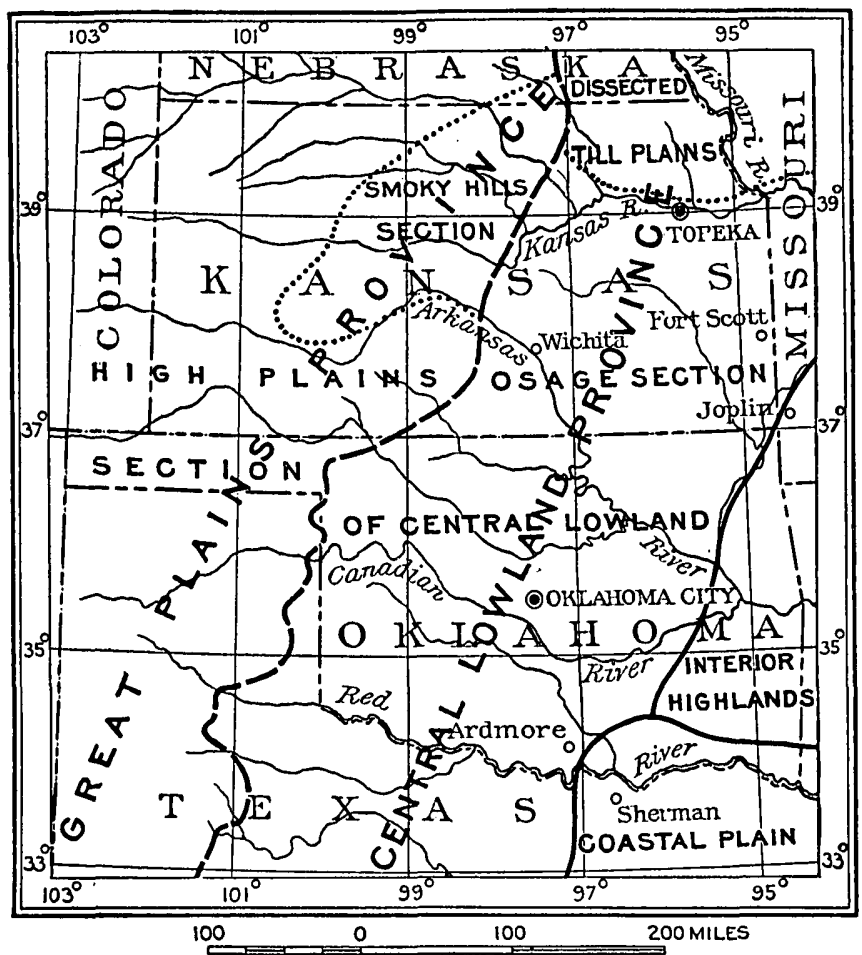

F'GoRe 44.-Physiographic sections in western Oklahoma and adjacent parts of Texas, as revised.

east beyond the Gypsum Hills in Blaine County; thence to Watonga and El Reno, crossing that line of Gypsum Hills three times; from El Reno south beyond Canadian River and northwest and west to Clinton, on the Washita; thence southwest across the North Fork of Red River and west to McLean, on the High Plains, in Gray County, Tex. The southward course in Texas lay not far from the High Plains escarpment as far south as Dickens County; thence southeast and east to Throckmorton County; thence in a zigzag line north and west to Quanah, Tex., and Eldorado, Okla. On the return trip through Oklahoma the course lay north to Mangum, in Greer County, and northeast over the flat plains among the out- 
lying granite knobs of the Wichita Mountains; thence, after a northward detour over the more rolling surface of Washita County, east to Anadarko and Chickasha, north to El Reno, and east to, Oklahoma City. The work was necessarily of reconnaissance character and insufficient to justify a full discussion of the physiography of the region, but the above outline of the route will enable those who are familiar with any of the broad areas that lie between the lines traversed to judge whether it is adequate and representative.

\section{TOPOGRAPHY ON THE SEVERAL FORMATIONS.}

\section{FORMATIONS RECOGNIZED.}

There is no marked contrast between the eastern and western parts of the area traversed with respect to the presence of nearly flat surfaces interpreted as remnants of a peneplain. The extent and flatness of such surfaces differs somewhat with the character of the underlying rock. The following formations are recognized in the area described:

Oklahoma :

Tertiary.

Permian :

Quartermaster formation.

Greer formation.

Woodward formation.

Blaine formation.

Enid formation.

Pennsylvanian.
North-central Texas:

Later Cenozoic.

Comanche (Lower Cretaceous).

Triassic (Dockum formation).

Permian :

Double Mountain formation.

'Clear Fork formation.

Wichita formation.

Pennsylvanian.

The United States Geological Survey correlates the Double Mountain formation of Texas with the Greer and Quartermaster formations of Oklahoma, the Clear Fork formation of Texas with the Enid, Blaine, and Woodward formations of Oklahoma, and the Wichita formation of Texas with the Chase, Wellington, and Marion formations of Kansas.

\section{OKLAHOMA PART OF THE AREA.}

\section{ENID FORMATION (PERMIAN).}

In Oklahoma the Enid formation is noteworthy for its great thickness ${ }^{2}$ of shale and weak sandstone and a relative absence of escarpment-making beds. It therefore forms the substratum of a wide belt of very low relief in middle Oklahoma. ${ }^{3}$ (See Pl. XVI, B.) There are, however, minor escarpments or hilly belts (Pl. XVII, $A$ )

\footnotetext{
${ }^{2}$ C. N. Gould (U. S. Geol. Survey Water-Supply Paper 148, p. 44, 1905) estimates the thickness as 1,200 to 1,500 ,feet.

${ }^{3}$ George I. Adams (Physiographic divisions of Kansas: Am. Geog. Soc. Bull., vol. 34, p. 95, 1902) calls this the Oklahoma Prairie.
} 


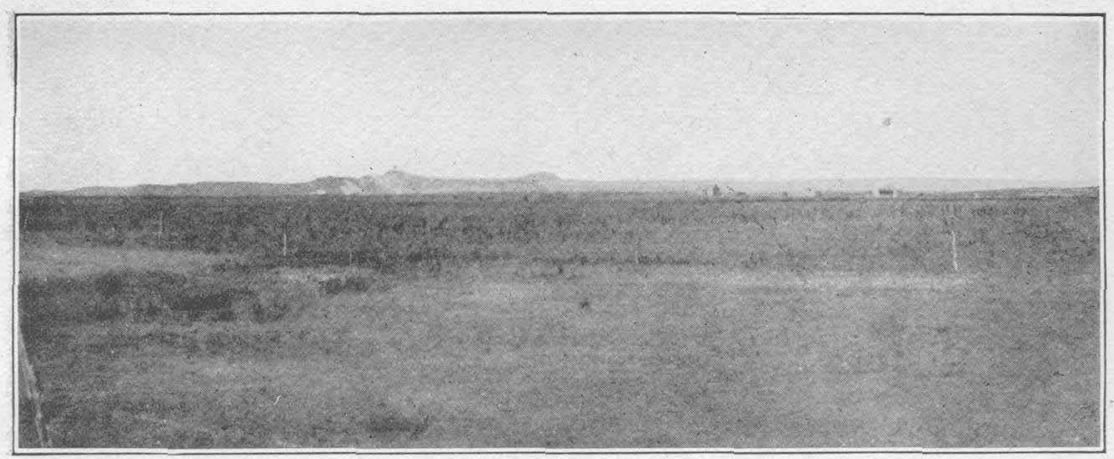

A. EASTERN ESGARPMENT OF THE HIGH PLAINS, HALL COUNTY, TEX.

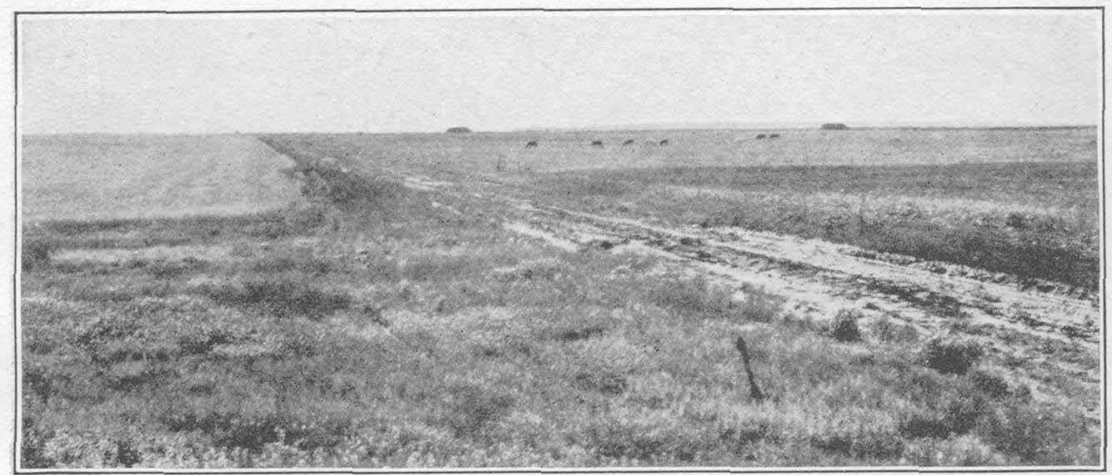

B. PENEPLAIN ON ENID FORMATION SOUTHWEST OF ALVA, OKLA.

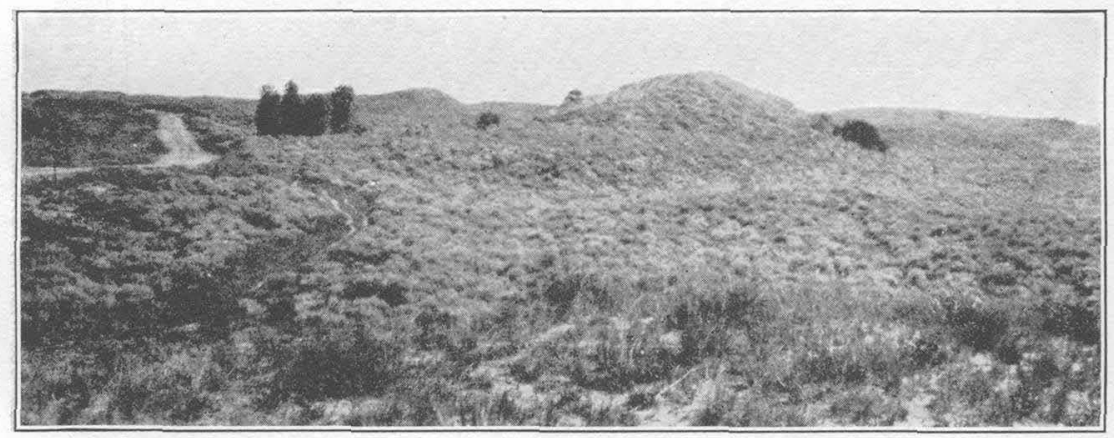

C. SAND DUNES NEAR CIMARRON RIVER, WOODS COUNTY, OKLA.

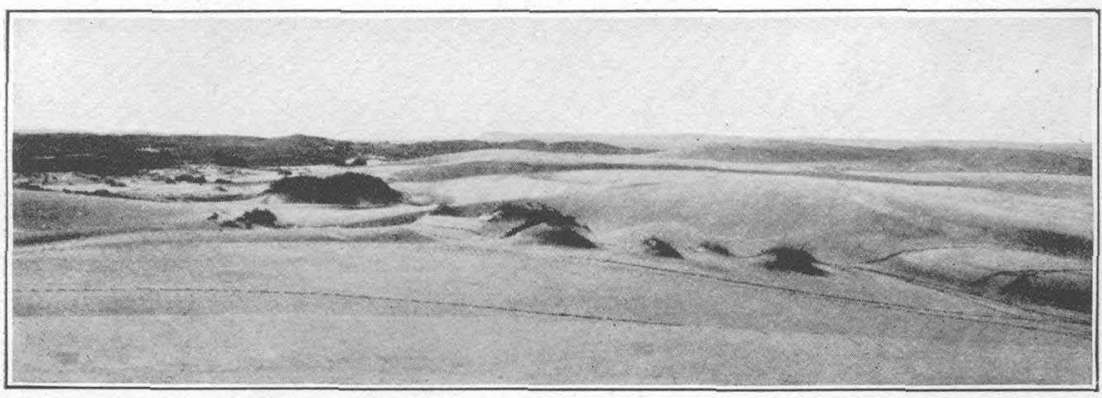

D. FIXED DUNES NEAR CIMARRON RIVER, WOODS COUNTY, OKLA. 
within the area of outcrop of the Enid formation, especially on the east side. Farther south in Texas the rocks are less uniformly weak, the escarpments are more pronounced, and the peneplain is less perfect.

\section{PENNSYLVANIAN SERIES.}

The Pennsylvanian series farther east and the higher formations of the Permian series farther west include beds of more unequal resistance to erosion. In southeastern Kansas and northeastern Oklahoma the Pennsylvanian underlies the most typical portion of the Osage section of the Central Lowland. This portion consists of belts of peneplain trending east of north, separated by escarpments, or narrow hilly belts, in each of which the general level rises westward by 50 to 200 feet. The whole region, therefore, resembles a stairway in which the risers are measured in feet and the treads in miles.

FORMATIONS ABOVE, I'HE LNID RORMATION.

The surface on the higher Permian formations to the west is less smooth than that on the Enid formation. Aside from features due to aridity, it is more like that of northeastern Oklahoma. The general aspect is that of a peneplain, with the differences mentioned below. The plain is quite as perfect on the west side as on the east. Flat areas within sight of the Tertiary escarpment are as large and as flat as those near the Enid. (See Pl. XVI, $A$ and B.) Several escarpments are noteworthy.

Escarpment of Blaine formation.-The Enid formation is overlain by the Blaine formation, which occupies the belt next west of it in northern Oklahoma. The Blaine is 75 to 100 feet thick and is the most prominent gypsum-bearing formation in the State, and its outcrop belt, almost throughout its length, forms a pronounced escarpment known as the Gypsum Hills or "Gyp" Hills. This escarpment is in places deeply and sharply dissected, producing a belt of rugged country that ranges in width from a fraction of a mile near El Reno to 4 or 5 miles along Cimarron River in the northwestern counties of the State. When this escarpment is approached from the east in northern Oklahoma, it appears to be a well-marked physiographic boundary. Moreover, within a few miles west of it, at least in places, there is another marked escarpment. $A_{S}$ the distance between the Blaine escarpment and the edge of the High Plains is here only 30 to 60 miles, as the rise across the strike is about 16 feet to the mile, and as the intervening belt is traversed by one major valley (North Fork of Canadian River) and contains abundant sand dunes, it will be seen that if this part of the State alone were considered, there would be some justification in regarding 
this line of the Gypsum Hills as the western limit of the Central Lowland.

The "break of the plains" here trends southwestward and the Blaine escarpment trends southeastward, so that, owing to this divergence, only a short distance to the south the two are separated by an interval of more than 100 miles. The surface of the wide belt between them differs but slightly in character from that of the plain east of the Blaine escarpment, which, moreover, disappears north of El Reno, in latitude $35^{\circ} 30^{\prime}$, leaving the so-called Plains Border without a natural boundary on the east for the remaining two-thirds of its length in Oklahoma and Texas.

Sandstone beds of the Woodward formation.-The Permian formations that underlie the surface west and south of the Blaine escarpment are fairly uniform in physical character, consisting mainly of red shale and sandstone. In their effect on topography they afford no contrast and offer no suggestions as to the division of the area into physiographic units. The most conspicuous escarpment maker in the Woodward formation is the Whitehorse sandstone member. In eastern Woodward County, several miles west of Quinlan and only 5 or 6 miles west of the Blaine escarpment, this sandstone forms a rugged escarpment more than 100 feet high, sharply dissected by young valleys, some of them 100 feet deep. This member is described ${ }^{4}$ as forming conspicuous buttes and meșas 100 to 200 feet high from Kansas southward beyond Washita River to latitude $35^{\circ}$. These rugged, angular hills of intensely red sandstone give a striking character to the landscape and, so far as they go, would justify the recognition of the area in which they occur as a distinct physiographic unit, but they are relatively isolated. The observer need only turn his back on them to see broad, flat, or gently rolling surfaces, indistinguishable in topography and vegetation from the peneplain on the Enid formation. Not only do the buttes, mesas, and escarpments occupy a minute proportion of the total surface, but the area within which such features are in view is, by. comparison, insignificant.

In southern Kansas the Whitehorse sandstone member is an important element in the great escarpment which lies at the edge of the High Plains in their long eastward extension within the "big bend" of Arkansas River. The dissection of that escarpment has made the Red Hills. At the south, in Oklahoma, this escarpment, together with that of the Blaine formation, turns northwestward along the Cimarron to make the narrow $V$ whose sides face each other across that river. Farther south, toward Watonga, El Reno, and

4 Aurin, Fritz, Geology of the red beds of Oklahoma : Oklahoma Geol. Survey Bull. 30, p. 28,1917 . Most of the localities of buttes and mesas described by Aurin have been seen by the writer. 


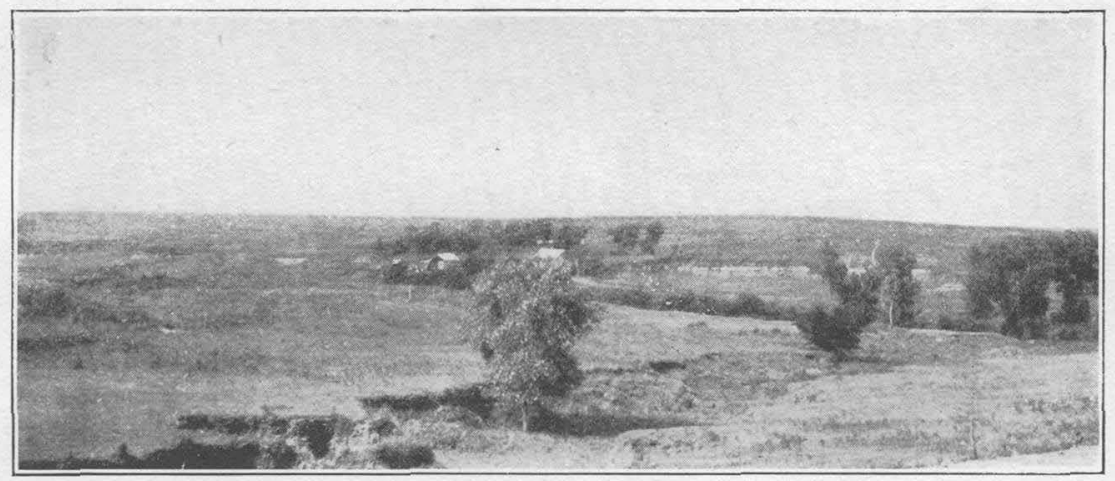

A. RELIEF ON STRONGER SANDSTONES OF ENID FORMATION NEAR A LARGER VALLEY, WESTERN BORDER OF GPANT COUNTY, OKLA.

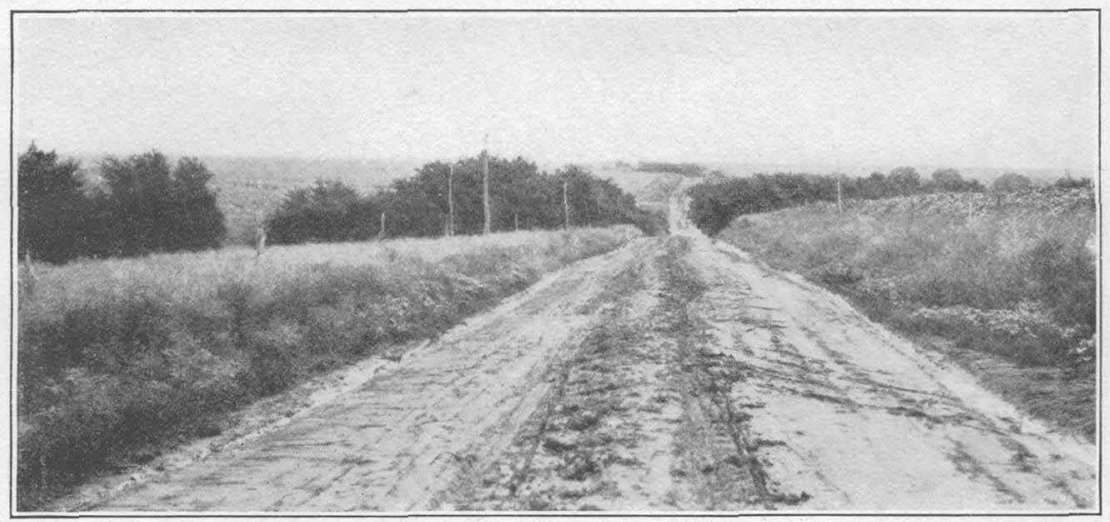

B. RELIEF ON GREER FORMATION NEAR A LARGER VALLEY, NORTHERN BORDER OF DEWEY COUNTY, OKLA.

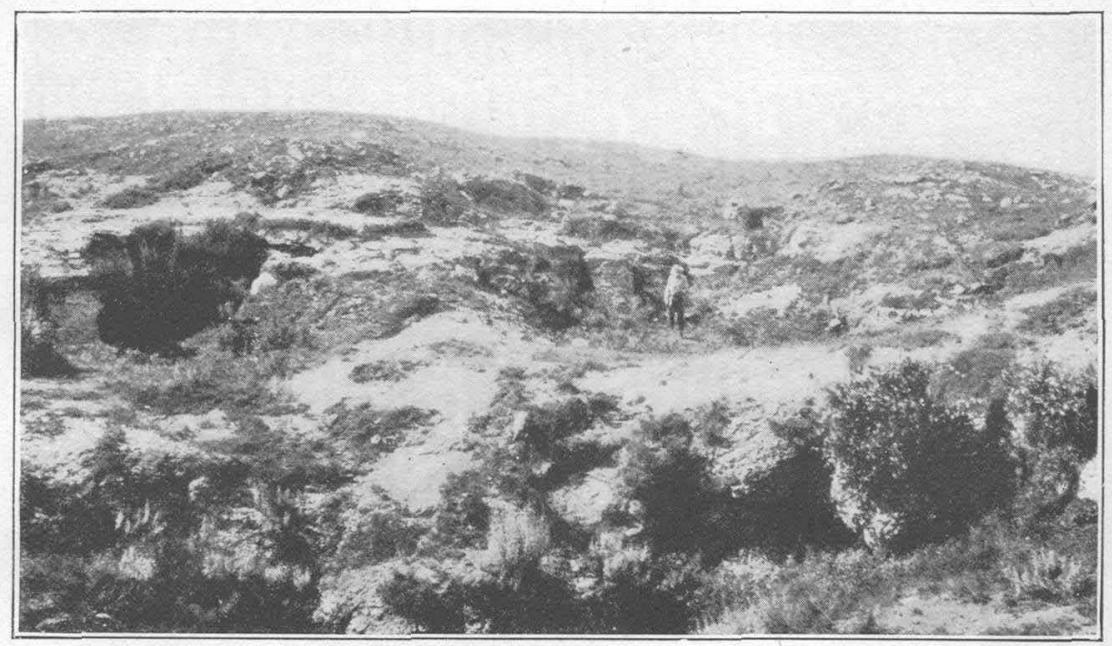

C. SINK HOLES IN GYPSUM ESCARPMENT, 4 MILES WEST OF SHAMROCK, WHEELER COUNTY, TEX. 
Chickasha, the rugged aspect of the escarpment is less marked, but the sandstones of the Woodward formation tend to maintain a slight elevation above the surrounding country, as in Blaine County; or to give a more sharply rolling character to the divides, as between North Canadian and Canadian rivers west of El Reno; or to make high, bold bluffs now subject to revived erosion, as east and west of Anadarko.

Greer and Quartermaster formations.-The topography on the Permian formations above the Whitehorse sandstone, as recognized by the Oklahoma Geological Survey, ${ }^{5}$ is for the most part rolling rather than flat (Pl. XVII, $B)$, but there are also broad areas of approximate flatness. So far as seen by the writer, such flat areas are more marked and extensive farther west in the "panhandle" of Texas.

\section{" RED BEDS" OF UNCERTAIN RELATION.}

The descriptions thus far given apply to that part of the area considered that lies north of the thirty-fifth parallel. On the Oklahoma geologic maps a large area surrounding the Wichita Mountains appears as "Red Beds of uncertain relation." It might well be inferred that the reason for this uncertainty is to be found in the weakness of the rocks and a consequent lack of outcrops, the surface being therefore one of low relief. This inference as to topography agrees with the facts as described by Taff $^{6}$ and as observed in the reconnaissance by the writer. On the west side of the Salt Fork of Red River, which flows south in Harmon and Jackson counties, are some bluffs, mesas, and uplands that rise more than 200 feet above the stream. The escarpments contain prominent beds of gypsum and sandstone. West of these escarpments the relief is less and the rolling surface merges into a broad peneplain. East of Salt Fork is the wide low plain that surrounds the Wichita Mountains and their outlying granite knobs. This plain east of the North Fork is coextensive with the area designated on the geologic maps of Oklahoma "Red Beds of uncertain relation." From 6 to 10 miles north of the Chicago, Rock Island \& Pacific Railway this plain abuts on the north against a higher rolling surface marked on the geologic maps as occupied by the Greer formation. On its east side the plain in like manner ends against the long southeastward extension of the Greer formation, the surface of which is more strongly rolling.

If this locality alone were considered the line of contact shown on the geologic map might perhaps be used as a boundary for physio-

\footnotetext{
5 See map, Oklahoma Geol. Survey Bull. 11, p. 128, 1913.

- Taff, J. A., Prelimlnary report on the geology of the Arbuckle and Wichita mountains in Indian Territory and Oklahoma : U. S. Geol. Survey Prof. Paper 31, pp. 72-74, 1904.
}

$79153^{\circ}-23-9$ 
graphic subdivisions, but the contrast in physiographic character is probably too small to justify divisions so important as sections. Moreover, as already mentioned, the sharp relief just west of this boundary is of very slight extent and is not representative of a broad area.

\section{TEXAS PART OF AREA.}

Escarpment of Permian rocks near Throckmorton.-The Permian rocks change in character remarkably both northward and southward from central Oklahoma. In both directions the red color disappears and the thick beds of shale and generally weak sandstone give place to shale and limestone. Different sets of formations are recognized in Oklahoma and in Texas (see p. 120), and the correlation of the two sets is not finally determined.

In Texas escarpments appear along horizons not thus marked in Oklahoma. Some of them, if extended northward along the strike, would cross the low plains on the "Red Beds of uncertain relation" around the Wichita Mountains. Others would appear in the more strongly rolling surface to the east or to the west.

The easternmost of these escarpments in Texas seen by the writer lies a little west of the ninety-ninth meridian. (See fig. 43.) It trends slightly west of south and passes the villages of Throckmorton and Albany. In places it consists of several rather than a single escarpment, and it becomes higher and more ruggedly dissected toward the south, where its total height is 150 to 250 feet, but on the north it dies out in a wide sloping belt near Red River. The belt of dissected escarpments near Throckmorton (the southernmost place reached on the trip) is at least 10 miles wide.

This series of escarpments is produced by resistant limestone beds in the upper part of the Wichita formation.? East of it lies an "irregular rolling surface of moderate relief," 8 the southward extension of the flattest part of the Osage section in Oklahoma. Farther east are the lower sandstone escarpments of the Pennsylvanian formations. Approached from the east the change in physiographic character at the rough limestone escarpment near Throckmorton is impressive, but this rugged belt can not well be used as a physiographic boundary except for units of a smaller order than sections. In the first place, it dies out at the north in the midst of a wide plain; in the second place, it is succeeded on the west by plains 30 to 40 miles wide, broken only by intrenched streams that have begun anew to erode their valleys-features which, though to a less extent, appear in the rolling plain east of the escarpment and are not uncommon in the

'Gordon, C. H., Geology and underground waters of the Wichita region of northcentral Texas: U. S. Geol. Survey Water-Supply Paper 317, p. 8, pl. 1, 1913.

8 Idem, p. 8. 
flatter parts of central Oklahoma, even in the lowlands on the Enid formation.

Escarpments of Permian rocks near Aspermont.-West of Throckmorton plains extend completely across Haskell County, a distance of 30 miles, and overlap into adjacent counties, where they abut against an 80-foot escarpment of gypsum and dolomite 6 miles east of Aspermont, in Stonewall County. This escarpment, with its companion 7 miles farther west, is the local representative of the "Gypsum Hills." It was not followed northward and southward, and data to show its exact correlation are not available. It may indicate the outcrop of the same beds that come to the surface at the western limit of the plains on the "Red Beds of uncertain relation" in Oklahoma. If so, there is here another line which might be used as a minor physiographic boundary. It is subject, however, to the same comment as the others, namely, that the landscapes on its two sides show little or no contrast.

Seven miles west of this escarpment is another, of about the same height, made by beds of gypsum and sandstone. Between the two escarpments is a strip of nearly flat plain in which lies the town of Aspermont.

Peneplain in Texas part of the area.-The top of the escarpment west of Aspermont affords a wide view of a peneplain which extends thence westward to the "break of the plains"-that is, to the relatively narrow strip of rough country which fringes the eastern edge of the Tertiary rocks. The distance across this peneplain is about 50 miles. The route followed leads northwestward to the towns of Spur and Dickens, in Dickens County.

The peneplain as observed in the first line of counties east of the High Plains (Kent, Dickens, Motley, Hall, Collingsworth, and Wheeler counties) compares favorably in its perfection.with that seen on any other part of the route traversed in the two States, except that the Enid formation no doubt affords flat areas of greater extent, even if not flatter.

Here and there on this western part of the peneplain are buttes and mesas, much the most prominent of which is Double Mountain. Most of the others are close to the escarpments, of which they are outlying remnants. They impair the perfection of the peneplain much less than the intrenched streams. As stated above, these streams do not differentiate the area here considered from the Osage section, unless by the degree of their rejuvenation.

THE "BREAK OF THE PLAINS."

The escarpment at the eastern edge of the High Plains is generally clear, though not everywhere equally bold (Pl. XVI, $A$ ). 
In only one of five counties in which it was approached or ascended in Texas does it fail to rise conspicuously on the western horizon. The exception is the northernmost county, Wheeler, in which it was approach at one place only. (See Pl. XVII, C.) At that place a rise of 500 feet is accomplished in about 10 miles west of the village of Shamrock, and throughout much of this distance sand dunes prevail. A semidetached eastward extension of the High Plains in Ellis County, Okla., north of Canadian River and the thirty-sixth parallel, shows a similar slope likewise dotted with sand dunes. Such gradation with lack of a definite escarpment will probably be found to be general between the thirty-fifth and thirty-seventh parallels.

The escarpment at the edge of the Tertiary area is most prominent where the Tertiary beds rest on resistant underlying rocks. In southern Kansas the escarpment is due to Cretaceous beds and Permian formations that have already been described. From the Kansas-Oklahoma boundary south to the thirty-fifth parallel, along the edge of the High Plains, Tertiary gravel rests on upper Permian formations, in which no strong escarpment-making members are known to the writer. It is not to be expected that this part of the High Plains boundary will be found to be as clear and distinct as other parts.

South of Red River the eastern edge of the High Plains coincides essentially with the outcrop belt of the Triassic Dockum formation and still farther' south with that of the Cretaceous limestones. Udden ${ }^{\circ}$ states that the "North-Central Plains" are bounded "on the west by the high erosion escarpment of the Pan Handle High Plains and the Llano Estacado," thus implying the presence of an eastward-facing escarpment throughout the length of the High Plains in this area.

\section{SOME PRINCIPLES OF EROSION IN ARID CLIMATES.}

Some physiographic features of this region can not well be described in terms suited to conceptions of erosion in more humid climates or on rocks of other character; therefore, as a preliminary to the physiographic history of the region, a brief description of these forms and the processes by which they were made will be given. It is convenient first to consider the effect of erosion as illustrated in the smaller forms, beginning with the gully, and to proceed thence to larger features and the larger questions involved.

Gullies in general.-The physiographer's conception of the progressive dissection of peneplains, as of other plains, is based mainly on the growth of gullies. Rapid down cutting, steep sides, V-shaped cross section, and branching enter most abundantly into his mental

' Udden, J. A., Review of the geology of Texas: Texas Univ. Bull. 44, p. 18, 1916. 


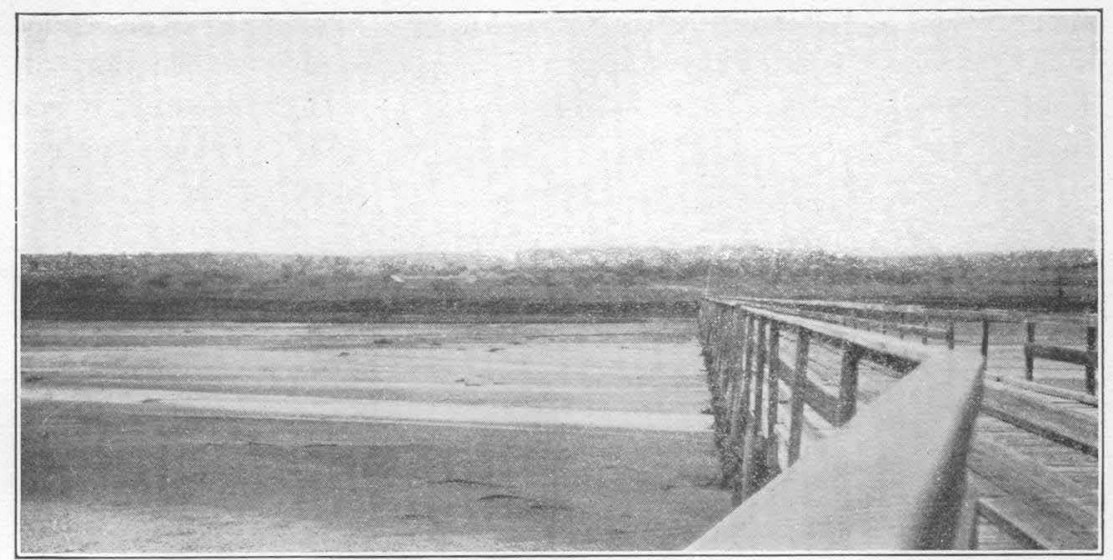

A. PRAIRIE DOG FORK OF RED RIVER, HALL COUNTY, TEX.

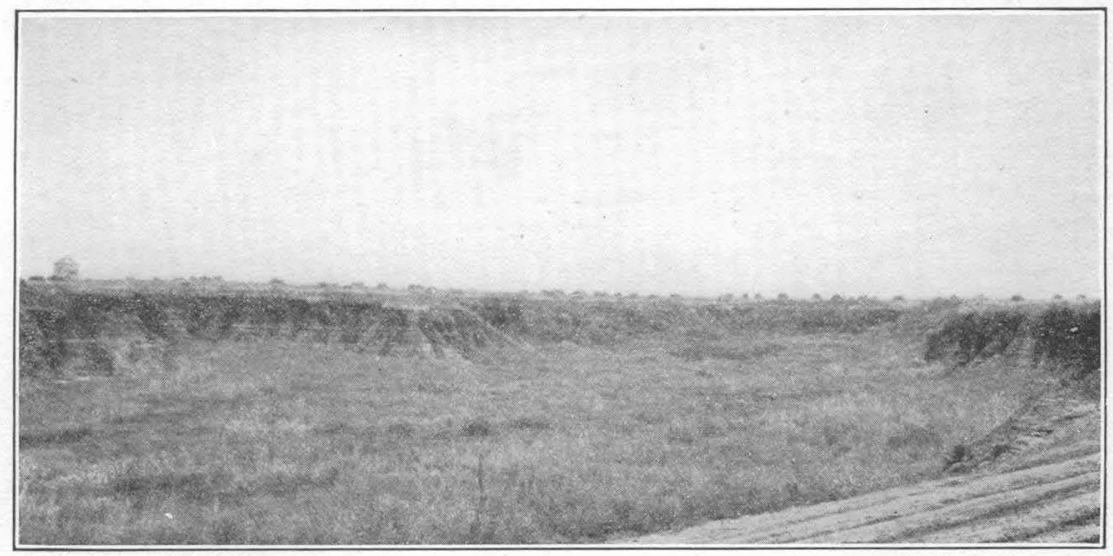

B. GULLY WITH RECEDING ESCARPMENTS, GRANT COUNTY, OKLA.

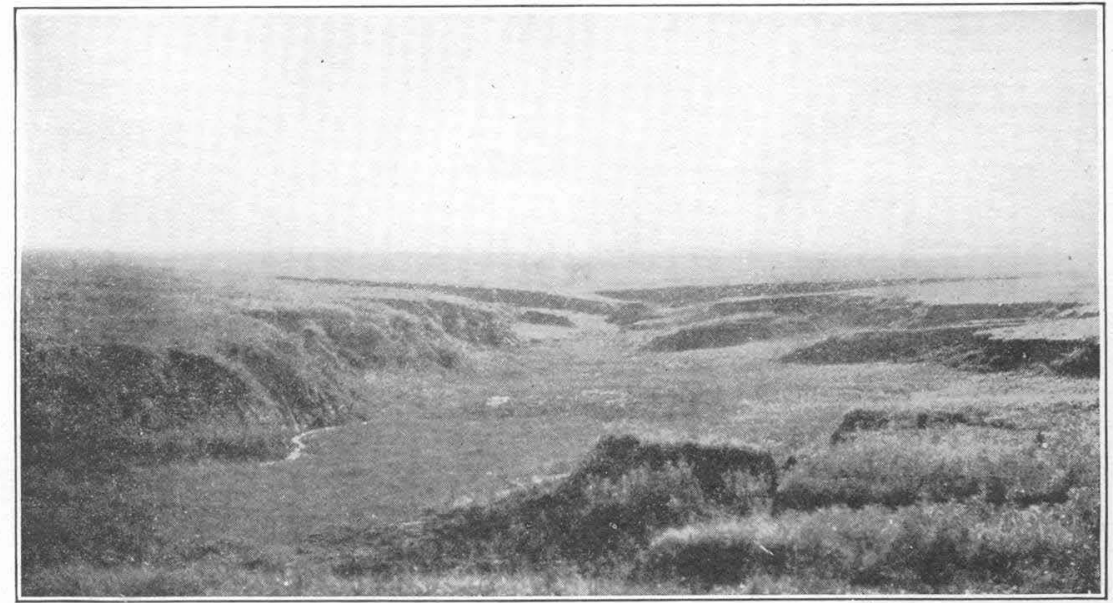

C. OLD VALLEY REJUVENATED, NORTH OF CHICKASHA, OKLA. 
pictures of an upland of homogeneous material or horizontal rocks that is undergoing dissection, especially when erosion is vigorous.

Lack of branching in gullies of arid regions.-The first modification of this conception is made necessary by the fact that many gullies in semiarid regions like the one here considered do not branch at all. Others show only incipient branches, so wide in proportion to their length that the gully wall is scalloped in a series of open alcoves. Gullies having walls retreating in this way have almost flat bottoms, many of them very wide. The flat bottom is not unknown in humid regions, nor is the V-shaped branching gully unknown in arid regions. ${ }^{10}$ "Badlands" are indeed commoner in arid than in humid regions, but the conditions favoring the development of the flat-bottomed "draw" ${ }_{11}$ (Pl. XVIII, $B, C$ ) with retreating walls are more commonly associated with aridity than with humidity.

The suggestion that such forms are favored by alternate beds of different character and that they are the beginnings of stratum plains contains some truth but is inadequate. Two facts bearing on this point may be recalled-that such forms are common on the High Plains in the unconsolidated Tertiary formations, and that their flat floors may have a steep slope downstream, even though horizontal in cross section.

Percolation of surface water as a factor.-The absence of branching is no doubt due primarily to the dominance of percolation as opposed to run-off. Where all the water goes into the ground no channels form. A steep edge of homogeneous dense clay could not escape dendritic dissection. This factor of large percolation is more common in arid regions because of the dryness of the ground and the depth of the water table, but aridity is not essential.

Wind as a factor.-A second factor is the work of the wind. The drier the ground the more effective is the wind in filling incipient channels and erasing the effect of one rain before another comes. Long intervals between rains and scarcity of vegetation make wind more effective. As all gullies have small beginnings, it is not strange that in arid regions many incipient branches should be checked in their growth by the work'of the wind and that some gully walls should retreat long distances without dissection.

${ }^{10}$ Dutton, though stating that denudation in arid regions is accomplished largely by recession of cliffs rather than by down-cutting, lays stress on the fact that the Vermilion Cliffs, in the Grand Canyon region, are cut by numerous branching canyons (U. S. Geol. Survey Mon. 2, p. 62, 1882). From the writer's observations it would appear that, although such dissection affects the rate of recession, it is by no means the cause af the preponderance of lateral stripping over vertical down-cutting, nor is it going on in all areas that show lateral denudation.

"The word "draw" is frequently used on the Great Plains to designate a small, shallow valley, regardless of the form of its sides. The word is used here in the colloquial sense to. designate such a valley that started as a gully but has become so wide that the application of the term "gully" would be misleading. 
A consequence of this checking of gullies in their incipient stages is seen in the "coarse texture" of dissected plains in arid regions. Apart from the absence of trees, the casual observer thinks there is something typically "western" (arid) about the long, unbroken slopes of the Great Plains, where they are not flat.

Sapping.-However, why does the gully wall retreat, and why does it remain vertical? Manifestly the second condition depends on the first, as no cliff continues long to be vertical or even steep unless it. does retreat. The manner of retreat is therefore the critical point.

In humid climates corrasion by direct run-off is the main factor in the development of most gullies, hence down cutting is dominant and widening and headward lengthening are merely incidental to down cutting. With increase of percolation, however, corrasion becomes much less effective, its effectiveness decreasing in geometric ratio to the decrease in the amount of run-off, and the lessened down cutting is accompanied by lessened lateral and headward growth of the gully. This is offset by sapping, as the percolating water that did not cut back the escarpment by corrasion accomplishes the same result by sapping at the base of the scarp.

Sapping, therefore, is the dominant factor in determining the form of the flat-bottomed, scarp-bordered gully or "draw" of arid regions. At some places landslides are effective, and where the underlying beds are shale mud flows may be a prominent or even the dominant factor in the development of scarps. Wind is no doubt one of the chief agents, if not the chief, in removing waste from the foot of the scarp and thus preventing the process of recession from becoming self-limited.

Flat bottoms.-With its limiting escarpments thus receding the tendency of the gully to become a flat-bottomed draw is apparent. Where drainage from a considerable area centers in the draw the preservation of the flatness of its bottom is surprising, and it seems a safe inference that in all such draws the amount of sediment fed to the stream during a freshet is greater than can be moved by the current, at least during the subsidence of the freshet. Hence any channel begun during the earlier stages of the flood is later obliterated by deposition. Almost all streams are "overloaded" during the subsidence of a flood, and even a gully in a humid region is apt to have a narrow sandy flat resting temporarily in the bottom of its $V$.

Depth of the draw.-The depth of the draw or the height of its walls-that is, the level at which the flat bottom is maintained-is controlled by a combination of factors, one of which is evidently the inability of the stream to transport all the débris supplied to it during the subsidence of freshets. The existence of nearly horizontal resistant beds that may act as local base-levels for the stream is 
another, and less obvious factors are the depth of the water table and the state of the soil above the water table, especially with respect to its content of moisture and salts. It can not be assumed that the base of the escarpment is generally as low as the water table or that ground water issues along it in springs, as other factors help to locate the horizon of effective sapping. Arid soils contain abundant salts, which cement and indurate the soils more at some levels than at others, and they tend to concentrate in the upper soil and to accumulate and form "mortar beds" near the water table. Unequal vertical distribution of this cementation may be an important factor in determining the horizon of sapping in an otherwise homogeneous formation.

Terraced draws.-It is not uncommon to find a new gully furrowing the floor of a wide, flat-bottomed draw. At first sight this might be interpreted as indicating a new cycle of erosion. It should be remembered, however, that conditions of the same sort as those which preserved the original surface from dendritic dissection, though in an exposed position and above its local base-level, may for a long time preserve the new flat at the bottom of the draw. When, with the development of the valley, the time comes to cut the bed of the stream down to a new level, the same process may be repeated, and thus flat after flat may be formed more or less rhythmically without any change in the regional base-level. No doubt, also, minor or temporary climatic changes or changes in vegetation cause many newly made valleys to be aggraded and degraded again within short periods.

Larger valleys.-The discussion has thus far concerned itself with gullies and draws because the mechanics of growth and change are clearer in those than in large valleys, but the same principles evidently control the development of all. The same factors must also control the extensive stripping of stratum plains.

Near Ferguson, in Blaine County, Okla., the peneplain on the Enid formation is exceptionally well developed. In the midst of this nearly flat plain the headwaters of Salt Creek flow in a flat-bottomed valley 40 feet deep and a considerable fraction of a mile wide. The edge of this valley, where crossed-during the reconnaissance, is an abrupt escarpment marked by a very narrow strip of badlands but is straight for long distances and unbroken by any ravines within sight. If the escarpment is left out of view, here are two flat plains at different levels, one as flat as the other. A few hundred feet back from the top of the escarpment the peneplain is not being worn down by streams. At 200 feet out from its foot the lower plain is perfect. This lower plain is not a flood plain, nor is the escarpment an ordinary stream bluff. The stream has had nothing to do with making 
either feature except to lower the local base-level. It would appear that the gradient of Salt Creek is very moderate for so small a stream. The surface is simply being stripped horizontally. The rock is fine argillaceous red sandstone or sandy shale. There is no reason to think that an alternation of resistant and weak beds is a significant factor. This is one of many striking illustrations of the tendency toward rapid lateral stripping with little or no evidence of wearing down. Examples were found throughout the outcrop of the Permian "Red Beds," though few exhibit such vigorous escarpment cutting. The two significant and remarkable things about Salt Creek are that a plain only 40 feet above its local base-level should be attacked so vigorously and that there should be such a lack of dendritic dissection.

An extreme illustration of the same process is found in the valley of the South Fork of Wichita River in Knox County, Tex., a few miles north of Benjamin. Here the river has cut a trench 8 miles wide in one of the flattest plains in the region. The walls of the trench are between 100 and 150 feet high, and the floor is almost flat. Small residual masses stand upon it, but the relief is in few places more than 10 feet and is of such a character as to show that the stream has never meandered over more than an insignificant fraction of the valley floor. The one thing that the stream has done is to lower the local base-level. The rest of the trench cutting was done by lateral stripping. The limiting walls, though notched in a small way, are surprisingly straight, and no tendency to dendritic dissection was seen in the adjacent flat upland.

Stratum plains.-The mention of "stripping" at once suggests the denudation of certain resistant beds and the production of stratum plains, which need not be at the local base-level. In the valleys thus far mentioned no positive evidence was seen that the levels of the new and lower plains (the valley floors) were thus determined. The topographic results may suggest resistant beds beneath the valley floors, but it should be remembered that similar stripping is observed in gullies and draws where the control of resistant beds can not be assumed, and that the general appearance of these larger valleys suggests that the streams are at their local base-levels, thus making unnecessary the hypothesis of resistant beds.

Advancing once more in the scale of size, we come to the broad plains which lie between the major eastward-facing escarpments. Here there is definite evidence in the escarpments themselves that the relative resistance to erosion of the beds has been an important factor in fixing the levels of the several plains, at least near their eastern edges. To some extent, at least, these plains conform in origin to the customary conception of a stratum plain. 
Special conditions of valley cutting in scarped plains.-Another theoretical problem concerns the conditions of peneplanation and valley cutting peculiar to scarped plains (p.116). The redevelopment of escarpments in a second cycle implies that certain more resistant beds have been able, at least in part, to maintain temporary baselevels for stream basins above the escarpments. It is conceivable that peneplains may be developed on the intervening weak beds before the master streams flowing over the strong beds have cut down their profiles completely to the new base-level. Further lowering of the stream's bed across the hard rocks must then be accompanied by a corresponding down cutting within the limits of the intervening peneplains. The rate of such down cutting may be so slow that the local peneplains are lowered concurrently. On the other hand, values may be assigned to the several factors involved (resistance of escarpment rock and of overlying beds, power of streams, area of basins, etc.) which make it possible for the streams to cut shallow valleys in the peneplairs. The factors have not been evaluated in this area, but many of the streams, especially in the western part, occupy wide valleys of gentle slope, trenched by narrow valleys' between steep bluffs. It seems probable that these wide valleys are due to the conditions here described, which attend the wearing down of scarped plains and do not indicate a distinct uplift of the region, as does, presumably, the more recent and abrupt intrenchment.

Aggrading streams.-It is frequently assumed that the characteristic features of the stream channels of this region indicate aggradation-that is, the progressive filling of the valleys with alluvium. The features referred to are the exceedingly wide, flat channels showing at low water numerous sand bars among which the stream flows in "braided" fashion so long as any water remains in the channels (Pl. XVIII, $A$ ). Without doubt such features are characteristic of "overloaded" streams. There can be no question that when the features, visible at low water were formed the stream was supplied with more load than it could transport and was depositing more than it was removing. On the other hand, the major features of many of the valleys give no support to the assumption of progressive aggradation. They may even indicate the opposite. Terracing is common in the larger valleys. On the Prairie Dog Fork of Red River the 80 -foot terrace seen in the background in Plate XVIII, $A$, consists of laminated alluvium, the upper 40 feet of which stands with a vertical face a few hundred yards from the river. Necessarily such a terrace is a short-lived feature, and it can not have been very long since the stream cut down to its present level and exposed its earlier alluvium to erosion. Yet no stream could be found which presents in a more typical form the features commonly interpreted as indicating aggradation. 
The building of a sand bar is of course a more recent process than the cutting of a terrace, and it is not impossible that recent down cutting ha's given way to still more recent filling. Nothing is yet known, however, to invalidate the assumption that the aggradation noted is simply that which is incidental to the subsiding stages of every flood, and that during the rising stages of the floods more material is carried away than is deposited during the subsiding stages. The process of removal is of course not subject to direct observation, nor are its results except as seen in the larger features of the valley. The features due to periodic deposition are the ones that most appeal to the eye during 99 per cent of the time.

It follows from this that a so-called "overloaded" stream is not necessarily an aggrading stream in the sense that implies progressive or cumulative aggradation, but one which is supplied with a very large volume of detritus, some of which moves forward with each flood. Between such times the excess of Joad is stowed away, a part of it in sand bars but much the greater part of it in the thick sheet of sand and gravel that rests on the bedrock under the bed of the stream. If this sheet is so thick that the scour during floods fails to reach the rock beneath, then deposition has been cumulative and the stream has been aggrading, for the level of the bedrock surface is due to erosion.

As the possible depth of scour by such streams is not known, it can not be positively asserted that the scour always reaches the bedrock. The very few data obtained on the thickness of sand and gravel under channels seem to indicate that it is proportional to the size of the stream, and that this sheet of material, though thicker than would be casually assumed to be subject to scour, is not thick enough to warrant the positive conclusion that it is not subject to such removal. Depths to rock beneath the larger streams in this area seem to be fairly uniform-from 30 to 40 feet, or very little more. Under these circumstances much importance should be attached to the general features of the valley, as suggested above.

The additional fact that active gullying is in progress near the larger streams adds to the evidence that these streams are, on the whole, degrading their channels instead of aggrading. Too much weight should not be given to the evidence of gullies, however, in view of their intimate connection with vegetation, cultivation, grazing, etc. The distribution of active gullying has not been sufficintly studied to determine what the influence of these factors may be.

\section{SUMMARY OF PHYSIOGRAPHIC FEATURES AND HISTORY.}

Relief.-The region is in general one of slight relief, less than 100 feet in a mile on the average, and features showing relief of 200 feet 
are exceptional. Large areas are so nearly flat that the slopes should be called faint rather than gentle. The coarse-textured drainage pattern is an additional characteristic of a peneplain.

The more striking features of the relief are eastward-facing escarpments and intrenched valleys. In the southwestern part of the region steep-sided mesas are also noteworthy.

Streams.-The region from Arkansas River on the north to Brazos River on the south is crossed by a number of remarkably parallel streams. Probably nowhere else in the United States do so many main streams run so near together for such long distances. Most. of these streams are intrenched in relatively narrow valleys. They are characteristically but not universally attended, especially on their northeast banks, by belts of sand dunes from 2 to 10 miles or more wide (Pl. XVI, $C, D)$.

Indications of more than one cycle of erosion.-Indications of at least two cycles of erosion are widespread, and an additional rejuvenation has also occurred in màny places. The features suggesting two or more cycles are the intrenchment of all the larger valleys and many of the smaller ones and active gullying near some intrenched streams. All the main streams of the region were crossed in this investigation, most of them at more than one place. The Arkansas, Salt Fork of the Arkansas, Cimarron, North Canadian, Canadian, Washita, and the several forks of Red River and of the Wichita and Brazos are all intrenched below the peneplain level. Generally they are bordered by bluffs, more or less steep, the full height of which ranges from 50 to 200 feet. Where bluffs are lacking their place may be taken by long slopes. At many places, especially in the western part of the area, both bluffs and long slopes may be seen, the slopes rising for a mile or more from the top of the bluffs to the level of the upland. This is seen on most of the upper branches of the Red, Wichita, and Brazos. A revival of cutting power is, of course, indicated by the bluffs. Whether the -old valleys indicated by the gentle slopes belong to the cycle of peneplanation or to a later cycle remains undetermined by any field study yet made. Considerations mentioned above under "Special conditions of valley cutting in scarped plains" show that these slopes do not necessarily indicate revival of crustal uplift.

From the study made in the field it was not possible to correlate peneplains for long distances. The two cycles observed at one place may or may not correspond to the two cycles observed elsewhere.

Hypotheses respecting former base-leveling.-To what extent the entire area should be conceived of as having been peneplaned in the commonly accepted sense of that term (reduced nearly to base-level) is uncertain. If the entire area ever was a single peneplain, the present escarpments must have been produced by revival, and the 
several plain belts between them are either peneplains or stripped plains of a newer cycle.

Over against this conclusion may be set the hypothesis that the area was never one general peneplain and that the existing escarpments have been present, though retreating westward, throughout the process of denudation. It may be that in the general down cutting each escarpment-making member has determined a local base-level and that the plains west of it to the next escarpment were kept cut down to the local base-level by the ordinary processes of stream and interstream erosion. Again, it may be that these familiar processes were always subordinate, and that progressive lowering has been accomplished mainly by the westward recession of escarpments. The general straightness of the escarpments and, in a large way, the levelness of their tops favor the assumption of general peneplanation.

The remarkable parallelism of the streams requires the assumption of a very flat plain on which they originated. This may have been either a peneplain or the former eastward extension of the Tertiary mantle of the High Plains.

It seems probable, therefore, that there occurred in this region (1) the formation of a general peneplain, (2) one or more uplifts; and (3) the development of the present escarpments and intervening plains by renewed erosion in which lateral stripping as described above was prominent and perhaps dominant. This process would account for the typical steep-sided mesas found especially in the Texas part of the region. It would also explain the juxtaposition of other plains at diverse levels, which would otherwise require the assumption of distinet uplifts and partly completed cycles.

It is probably best to speak of these plains as peneplains rather than stratum plains. In any case they were developed by a combination of processes and probably at their local base-levels. "Throughout much of the larger part of the area they now have the characteristic topography of what is commonly called a peneplain. 


\section{INDEX.}

A.

Acknowledgments for aid._._._. 20

Adobe flats, description of

dunes on

Afton Junction, Iowa, glacial pebbles from, plates showing-

Aggradation, appearance of, by streams, in arid regions - . -

Ajo Mountains, Ariz., plates show. ing - - -

Albuquerque, N. Mex., former growth

Alinement charts, use of

Alluvium in the Papago country, Ariz

Page.

20,104

69-70

71

95

95

cer

42

80

96

28-32 of hay near

Altar Valley, Ariz., terraces in .... 73-74

Alva, Okla., peneplain southwest of, plate showing _......

Andrews Glacier, Colo., location of plate showing

Aridity, influence of, on erosion and sedimentation

Arivaca Creek, Ariz., terrace on

Aspermont, Tex., escarpments of Permian rocks near.--

\section{B.}

Baboquivari Mountains, Ariz., drainage course from, to Sonoita River._..._._. 67-68

Barajita Valley, Ariz., drainage course from, to Gila River.................

terraces in -

Basins, headwater, formation of -..-

"Benches, suballuvial." See Pedi. ments.

Black Canyon, Colo., features of - 12, 13-14 plate showing

Blaine formation, escarpment formed by, in Oklahoma_._. 121-122

Boulders, detachment of, on mountain slopes _._._. 39, 43-46

"Break of the plains," direction of, near the Gypsum Hills, Okla

form and position of prominence of escarpment at, in Texas c.

Cabeza Prieta Mountains, Ariz.,

Page.

lava-capped mountain

Canyon cycle, effects of erosion during ......... 5, 13-14

Canyons, cutting of ............ $46-48$

Central City quadrangle, Colo., map and profile section of part of

Central Lowland, location and alti. tude of _...... 115

Charco, use of term

Chasm, The, on Longs Peak, Colo., origin of 13

plate showing - 10

Chemical action in rocks, effects of - 41-42

Cirques, features of _........... 10, 13

plates showing .......... 10

Comanche Peak, Colo., cirque near, features of

cirque near, plate showing _... 10

Conglomerate, niches formed in_... 50,51

Continental Divide in Colorado_.... 7

Convexity gnge, plate showing ....-

Copeland Lake, Colo., moraine south of, origin of _..._... 11, 13

moraine south of, plate showing 11

Corrosion, action of _......... 46, 47, 48

Curvature of pebbles, measurement of -

Cycles of erosion, two recognized in. Colorado

D.

Detritus, deposition of, by streams

Developed edge, use of term

Disintegration, granular, of rocks, cause of 41

Dissection of mountains, cause of - 11

Double Mountain, Tex., location of - $\quad 125$

Draw, use of term

Draws, cutting of terraces in

factors controlling depth of .. 128-129

preservation of flat bottoms of, in arid regions.-..- 128

Dunes, in the Papago country, Ariz., occurrence of _..... 70-71

near Cimarron River, Woods . County, Okla., plates showing -........... 
E.

Enld formation, features of, in Oklahoma__._._. 120-121

Erosion, canyon cycle of 16-17 chemical processes of _--_----- 41-42 early, in the Rocky Mountains, in Colorado mechanical processes of in arid climates third cycle of -_-_-_-_-_- 2-3, 14 two cycles of, recognized in the Rocky Mountains, in Colorado

Escarpments, receding, on gully, plate showing....-

Estes Park, Colo., origin of plate showing -

Exfoliation of rocks, features of.--_ 40-41

F.

Faulting in the Papago country, Ariz _-

Felsite, erosion of

Fillman, L., determination of roundness of limestone pebbles by

113-114

Flatness ratio, formula for 93

Flats, adobe, description of ...... 69-70 adobe, wind deposits on

Flattop Mountain, Colo., plate showview northwest from, plate showing -......-

Flattop peneplain, in Colorado, correlation of

formation of modification of, by glaciers remnants of _.............. plates showing.

Flood, sheet, description of

Florissant, Colo., origin of gravel beds near..........

Fosisils, occurrence of, in the Papago country, Ariz_- 22, 23,24, 31

Fragments, separation of, from rocks

Front Range, Colo., profile across, showing relation of Flattop peneplain to Rocky Mountain peneplain.

G.

Georgetown, Colo., quadrangle, pencplain recognized in _- 1-2

Gidley, J. W., fossils determined by - 31, 32 Gila River, drainage course to, from

Barajita Valley -..-- 68

terraces on _..._...- 30-32, 71-73

Girty, G. H., fossils determined by 22,23 Glaciation, pre-Wisconsin, apparent results of -...-_- 12,13

Wisconsin, results of _._._._. 13 Glossary of physiographic terms_-- 86-90
Gneiss, closely fointed, erosion of -Page. Granite, erosion of, on mountain slopes_-_-_-_-_-_-_ $45-46$ niches formed in

Gravel beds near Florissant, Colo., origin of -

Great Plain's, location and altitude of

Greer formation, topography on, in Oklahoma and Texas.

Gregory, H. E., on the discrimination of classes of pebb]es _._._._._. 91

Growler Mountains, Ariz., faults in from the west, plate showing -. Gullies, branching of, influences affecting - . _..._. 126-127

in arid regions, features of _.- 127 in humid regions, features of _ 126-127 on mountain slopes, formation and filling of _._._._. 43-44

See also Draws.

\section{H.}

Hagues Peak, glacier on, naming of glacier on, plate showing.....

Hallett Glacier, Colo., features of -plate showing

Hallett Peak, Colo., plates showingHeadwater basin in the Sand Tank Mountains, Ariz_.---

High Plains section of the Great Plains, eastern escarpment of, in Texas, plate showing-_.-- 120

origin and features of

\section{I.}

Igneous rocks, accumulation of débris from Inscription painted on rock, persistence of

J.

Jackson Butte, Ariz., basalt of

K.

Kino, Father, description of Santa Cruz Valley by _._._ 78,79

Kirk, Edwin, fossils determined by

L.

Landslides, erosion by, in arid regions _............

Lava, cliffy slopes of, on the Ajo M o u t a in s, Ariz., plates showing mountain capped with, in the Cabeza Prieta. Moun. tains, plate showing-Lavas, bedded, erosion of --_-_-_-See also Volcanic rocks.

\section{西}


Little Ajo Mountains, Ariz., probable Mesozoic igneous rocks in

Longs Peak, Colo., plates showingThe Chasm on, origin of .....plate showing

timber-line tree on, plate sbow-

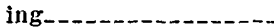

\section{M.}

McGee, W. T., cited Maricopa Mountains, Ariz., east slope of, plate showing-...-...........

felsite of outlier east of _-_-- 27_28 Measurement of pebbles, method of _ 93_96

Medicine Bow Mountains, plate showing ...................

Mesozoic rocks in the Papago country, Ariz

24_26

Mills moraine. Colo., features of _-- 9,13

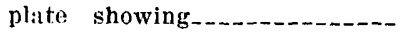

Monadnocks, examples of, on the Flattop peneplain in Colorado

Moraine Park, Colo., moraine south of, origin of .......

moraine south of, plate showing -

Mountain slopes, angles of, in the Papago country, Ariz_ 38, 42

angles of, influences controlling _._.

boulder-controlled, production and persistence of _-_ $43-46$

cliffy, production and persistence of -

conditions iletermining

grales of _._._._._. 38,42

plate showing -......_._._._. 60

rnin-washed, erosion of _...... 46

Mud flows, development of scarps by, in arid regions_.-

N.

Needles, The, Colo., plates showing- 7,12

Niches, formation of

Nogales Wash, Ariz., course of...- 74 valley of

Nomographic charts, use of

O.

Oklahoma, western, physiographic features and history of

Osage section of the Central Lowland, features of...- 116-1.17

\section{P.}

Paige, Siciney, cited.

Paleozolc rocks in the Papago country, Ariz., nature and age of
Papago country, Arlz., character of the mountains in._-- 36-37 former moist climate in _..... 78-80 geography of _._._._._._._. 19-20 geologic history of.......... 81-85 geology of _._._._._._._._._. 20-37 reconnaissance geologic map of _...... In pocket.

stratigraphy of

structure of _._._. 33-37

Tertiary events in.......... $82-53$

Tertiary rocks in _._._._.... 26-2s

Patagonia Mountains, Ariz., Comanche rocks in

Mesozoic igneous rocks in

Pebbles, field work on, method of - 106-109 glacial, from Afton Junction, Iowa, plates showing -

glacial and sand-blasted, before and after artificial abrasion, plates showing measurements of, plotting of - 97-102 original shapes of relation of roundness of, to size and to distance of transportation _.... 108-1.11

Pediments, dissected, plates showIng _.

mountain, burying of._._._. $58-60$ coalescence of dissection of._._.... 55, 60-65 formation of _..._. $48,54-58$ nature of _._.

Peneplain east of the High Plains in Texas, features of -

Feneplain southwest of Alva, Okla., plate showing -...-...

Pennsylvanian series, surface upon, in southeastern Kansas and northeastern Oklahoma _......... 121

Percolation of surface water, influence of, on the branching of gullies.-

Permian rocks, escarpment of, near Throckmorton, 'Tex- 124-125

escarpments of, near Aspermont, 'Tex______-_ 125

Phyllite, erosion of...... 46

rikes Peak, Colo., plateau near,

Pillars, formation of

" Platns Border," conclusions on - 118 feld work in _..._._._._._. 119-120

formations recognized in...... 120

problem of ___._. 117-118

Plains, scarped, cutting of valleys in

stratum, origin of

"Platforms, subaerial." Sec Pediments.

Playas, occurrence of _._._-__-_ $\quad 70$

Potrero Creek, Ariz., course of 
Prairle Dog Fork of Red River, Hall County, Tex., plate showing -..---_----

Pre-Cambrian basal complex in the Papago country, Ariz_-22-22

Prospect Mountain, view from, plate showing.

Q.

Quartermaster formation, topography on, in Oklahoma and Texas _._._...--

Quaternary deposits in the Papago country, Arlz

R.

Recession of mountain slopes, process causing

"Red Beds" hogback, plate showling

"Red Beds" of uncertain relation, topography . on, in Oklahoma___ _ 123-124

Relief on Enid formation in Grant County, Okla., plate showing.--..--

Relief on Greer formation in Dewey County, Okla., plate showing.--

Rigor, use of term

Rio Puerco, N. Mex., cutting of channel of

Rivers. See Streams.

Rock shelters, formation of

Rock spalls. See Boulders.

Rocky Mountain peneplain, evidence of

features of

furmation of _.............. modification of, by glaciers...remnants of, plates showing---

Rocky Mountains, profile across, through Longs Peak, events indicated by

uplift of

Roundness ratio, formula for......

Rupture of rocks, cause of

Russell Fork of Big Sandy River, Va., course of _._._- 105

quartzite on 105-106

\section{s.}

Sacaton Mountains, Ariz., Mesozoic igneous rocks in

Sand Tank Mountains, Ariz., faults in

headwater basin and dissected pediment in, plate showing----------

Santa Cruz River, Ariz., course and tributaries of _-_-

terraces along

Santa Rita Mountains, Ariz., Comanche rocks in

Mesozoic igneous rocks in
Page.

Santan Mountains, Ariz,, volcanic rocks of

Sapping, erosion by, in arid regions_ Scale, circular logorithmic, description of .-. 96

Schist, erosion of

Shapes of pebbles, original_____._ 92-93

Sierra del Pinacate, Ariz., lava flow from

Sierra Estrella, Ariz., Mesozoic igneous rocks in

Sierra type of mountain, process of carving _._._._._. $47-48$

Sink holes west of Shamrock, Tex., plate showing _.....-.- 122

Slopes of mountains. See Mountain slopes.

Sonoita Creek, Ariz., course of Sonoita River, Ariz., cutting of channel of.

drainage course to, from Baboquivari River._.___- 67-68

Sprague Glacier, Colo., location of _- 13 plate showing . 6

Stanton, T. W., fossils determined by 24

Stream, graded, use of term Streams, appearance of aggradation by, in arid regions_- 131-132 axial, in arid valleys 67-68 tributary, in arid valleys_._-_- 68-69 parallel, in Oklahoma a n d Texas -................

Tahosa Valley, Colo., features of 12,14

plate showing

Talus, formation and removal of _-- 43-46

Taylor Glacier, Colo., location of -- 13

Temperature of rocks, changes in .-- 39-41

Terraces, formation of, in the $\mathbf{P a}$ pago country, Ariz_-- 71-81

Texas, northern, physiographic features and history of - 132-134

Thompson River canyon, Colo., plates showing - $\quad \mathbf{7 , 8}$

Throckmorton, Tex., escarpment near _._.

Tuff, erosion of

Tule Mountains, Ariz., faults in

Tule Tank, Ariz., pass west of -..- 60

Tumacacori Mountains, Ariz., Mesozoic rocks in

Tumamoc Hills, Ariz., volcanic rocks of
96 
Tumbling barrel for abrasion of pebbles, plates showing-use of -

Tyndall Glacier, Colo., gorge below, features of

gorge below, plate showing-..location of plate showing

\section{V.}

Valley, rejuvenated, plate showing-- 126

Valleys, changes taking place in

drainage of origin of _. stripping of, in arid regions-- 129-130

Vekol Valley, Ariz., terraces and stream channels in_-- 80-81 $79153^{\circ}-23-10$

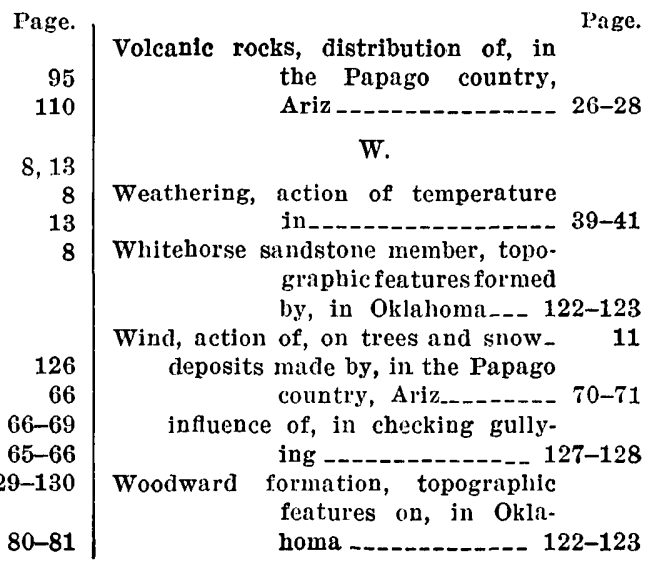

